\title{
Serum and tissue leptin in lung cancer: A meta-analysis
}

\author{
Xiang Tong ${ }^{1}$, Yao Ma ${ }^{1}$, Qilong Zhou ${ }^{2}$, Jie $\mathrm{He}^{3}$, Bo Peng ${ }^{4}$, Sitong Liu ${ }^{1}$, Zhipeng Yan ${ }^{1}$, \\ Xin Yang ${ }^{1}$, Hong Fan ${ }^{1}$ \\ ${ }^{1}$ Department of Respiratory and Critical Care Medicine, West China Hospital/West China School of Medicine, Sichuan \\ University, Chengdu, 610041, China \\ ${ }^{2}$ Innovative Drug Research Centre, Chongqing University, Chongqing, 404100, China \\ ${ }^{3}$ Department of Respiratory Medicine, The First Affiliated Hospital of Chengdu Medical College, Chengdu, 610500, China \\ ${ }^{4}$ Department of Internal Medicine, Hospital of Tradition Medicine LS.SC, Leshan, 614000, China \\ Correspondence to: Hong Fan, email: fanhongfanscu@sina.cn, fanhongfan@qq.com \\ Keywords: lung cancer, cachexia, leptin, risk, meta-analysis \\ Received: April 15, $2016 \quad$ Accepted: January 03, $2017 \quad$ Published: February 01, 2017
}

\section{ABSTRACT}

Many studies have found that leptin is involved in tumorigenesis and the progression of lung cancer. However, these studies were inconsistent. Therefore, we performed a meta-analysis to investigate the role of leptin in the patients with lung cancer. A systematic literature search in the several databases and on commercial Internet search engines was carried out to identify studies published up to July 8, 2016. The standardized mean difference (SMD) and odds ratio (OR) with $95 \%$ confidence interval (CI) were used to investigate the effect sizes. Finally, 21 eligible articles were included in the current meta-analysis. Overall, there is no relationship between levels of serum leptin and lung cancer. However, a subgroup analysis in highstudy quality group found a weak association between serum leptin concentrations and lung cancer in Chinese $(S M D=0.77, P=0.035)$. Additionally, the meta-analysis indicates that the serum leptin levels were lower in the weight-losing group than in the sustained weight group ( $S M D=-0.80, P=0.001$ ). Further, there was evidence of a significant association between expression levels of leptin protein in tissue and lung cancer $(O R=7.35, P<0.001)$. The present meta-analysis suggests that the serum and tissue leptin may be involved in the pathogenesis of lung cancer and tumor metastasis, especially among Chinese. However, the leptin may not appear to play an important role in cancer cachexia development.

\section{INTRODUCTION}

Lung cancer is the most lethal malignancy. The most recent cancer statistics report estimated that lung cancer accounts for approximately $26 \%$ of all female cancer deaths and $29 \%$ of all male cancer deaths [1]. Despite several significant advances in cancer treatment, the 5 -year relative survival for lung cancer is still less than $18 \%$ [1]. The main reasons contributing to the poor prognosis are the large population with advanced-stage lung cancer at diagnosis and the unsuccessful treatment in metastatic disease. Thus, there is intense interest in identifying novel biomarkers involved in this aggressive disease, for early diagnosis and to optimize its medical management. Previous studies have indicated many biomarkers considered as prognosticators, as well as indicators of screening and potential therapeutic targets for lung cancer, such as carcinoembryonic antigen, cytokeratin 19 fragment (CYFRA21-1), circulating cell free DNA, C-reactive protein, interleukin-6 (IL-6), and repetitive A (A type 3) [2-6].

Leptin, the product of the $o b$ gene, is a cytokine synthesized and secreted mainly by adipocytes [7]. It inhibits food intake and regulates energy metabolism by inducing anorexigenic factors and suppressing orexigenic neuropeptides [8]. The published studies have suggested that food consumption is associated with a transient increase in serum leptin levels, whereas fasting reduces $o b$ gene expression [7]. However, serum levels of leptin can be disturbed by other factors as well, such as various pro-inflammatory cytokines, including TNF-a, IL-1, and IL-6 [9]. Currently, leptin 
is also recognized as a polyfunctional cytokine, and it is considered to be involved in the pathogenesis of several cancer types, including breast cancer and pancreatic cancer [10-12]. Additionally, a growing body of studies has found that leptin is also involved in tumorigenesis and the progression of lung cancer. Among them, some studies have found that elevated serum leptin levels represent an independent risk factor for non-small-cell lung cancer (NSCLC) [1315], whereas other studies have reported significant correlation between decreased serum leptin levels and prognosis in lung cancer $[16,17]$. Further, a few studies have indicated that the expression of leptin protein was significantly higher in lung cancer tissues than in normal lung tissues $[18,19]$.

However, the observed relationships of these studies were inconsistent, and a single study may lack sufficient power to detect the possible small effect of the leptin levels on lung cancer, especially when the sample size is relatively small. Therefore, we carried out a most recent meta-analysis to accurately investigate the association between leptin and the risk of lung cancer, and to further assess the role of leptin in lung cancer.

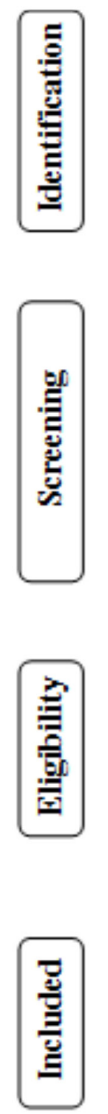

\section{RESULTS}

\section{Study characteristics}

We initially searched in PubMed, Embase, the China National Knowledge Internet (CNKI), Wanfang databases, and commercial Internet search engines, and we identified 213 articles according to the search strategy. As showed in Figure 1, 81 studies were excluded because they were duplicated studies, and 21 items were excluded because they were conference abstracts. After title and abstract screening, 71 articles were removed because they were not relevant to our study aim. After further, full-view screening, nine articles were excluded because they were not relevant to lung cancer in relation to serum leptin concentrations and/or the leptin protein expression levels of tissue. Three articles were eliminated because they were reviews. Four articles were removed because they were possibly repeated studies. Therefore, 24 articles were identified [13-18, 20-37]. However, three articles are completely omitted because these studies analysis falls out of a normal range for detection of serum leptin [22, $27,34]$. Finally, 21 eligible articles were included in the

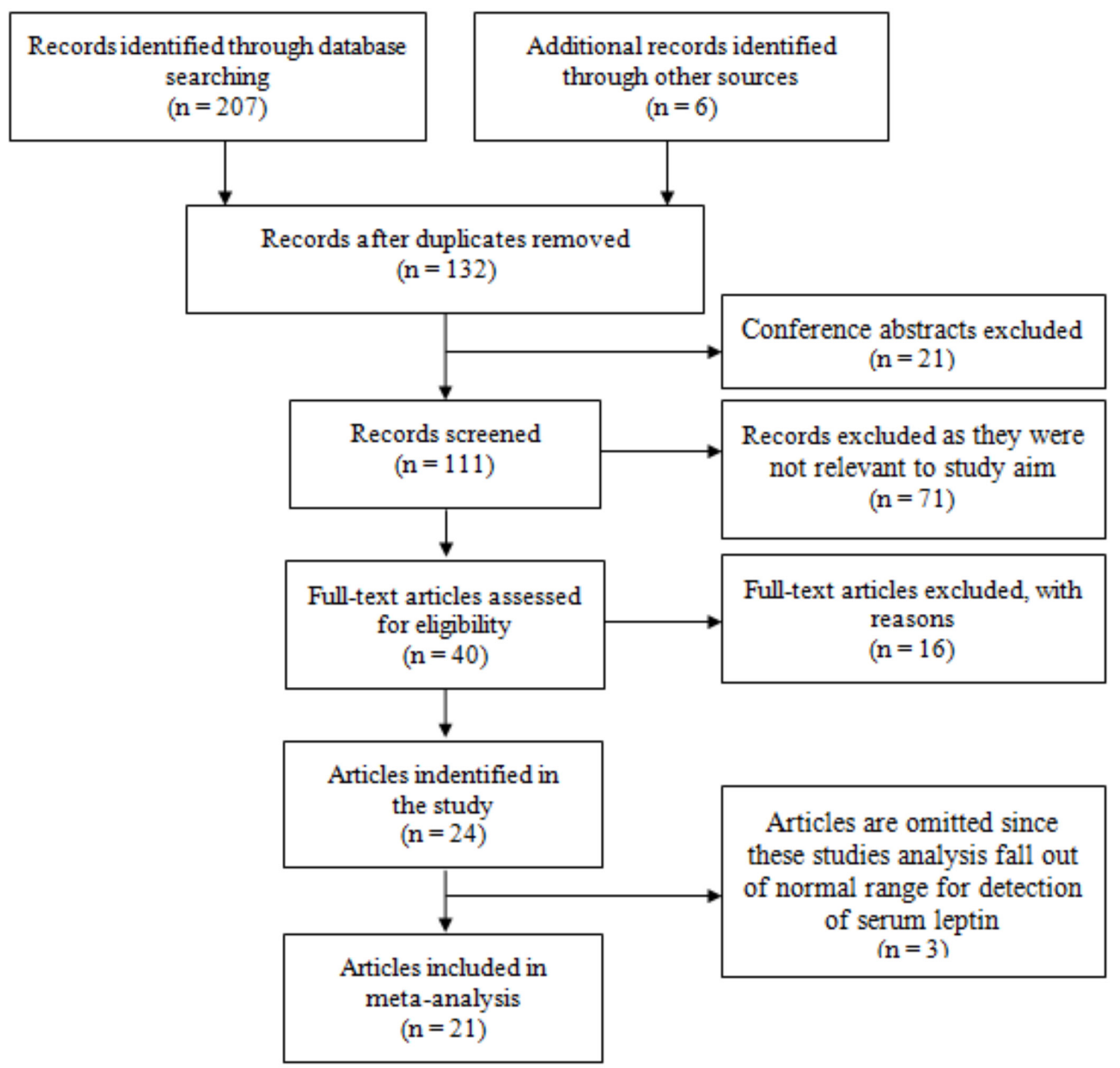

Figure 1: The flow diagram of the included and excluded studies. 
Table 1: Characteristics of studies involving association between the serum leptin and lung cancer

\begin{tabular}{|c|c|c|c|c|c|c|c|}
\hline \multirow[b]{2}{*}{ Author } & \multirow[b]{2}{*}{ Year } & \multirow[b]{2}{*}{ Ethnicity } & \multirow[b]{2}{*}{ Age } & \multirow{2}{*}{$\begin{array}{c}\text { Type } \\
\text { NSCLC/ } \\
\text { SCLC }\end{array}$} & \multirow{2}{*}{$\frac{\text { Stage }}{\text { I/II/III/IV }}$} & \multicolumn{2}{|c|}{ Weight loss } \\
\hline & & & & & & n (\%) & Status \\
\hline Aleman MR & 2002 & Europeans & $36-75 / 38-75$ & $76 / 0$ & $0 / 0 / 36 / 40$ & $30(23)$ & Untreated \\
\hline Carpagnano GE & 2007 & Europeans & $71 \pm 7 / 69 \pm 8$ & $32 / 0$ & $10 / 10 / 12 / 0$ & $\mathrm{NR}^{1}$ & Untreated \\
\hline Dong JH & 2009 & Chinese & $47.32 \pm 10.01 / 34.46 \pm 5.61$ & NR & NR & NR & NR \\
\hline Hong $\mathrm{X}$ & 2013 & Asians & $51.61 \pm 10.41 / 46.69 \pm 10.46$ & $0 / 41$ & NR & $15(36.6)$ & Untreated \\
\hline Jamieson NB & 2004 & Europeans & $43-79 / 46-74$ & $20 / 0$ & NR & $3(16.5)$ & Untreated \\
\hline Kerenidi T & 2013 & Europeans & $62.9 \pm 9.2 / \mathrm{NR}$ & $61 / 19$ & $11 / 14 / 26 / 29$ & $17(21.3)$ & Untreated \\
\hline Luo NP & 2008 & Chinese & $53.0 \pm 12.0 / 50.0 \pm 15.0$ & NR & NR & NR & NR \\
\hline Mou WJ & 2014 & Chinese & $30-69 / \mathrm{NR}$ & $27 / 0$ & $\begin{array}{c}0 / 0 / 4 / 21 / 2 \\
\text { (Unclear) }\end{array}$ & $2(7.4)$ & Untreated \\
\hline Song CH & 2014 & Chinese & $30-83 / / 29-76$ & $97 / 29$ & NR & NR & NR \\
\hline Tao XN & 2003 & Chinese & $32-71 / 29-68$ & $25 / 9$ & $0 / 17 / 13 / 4$ & NR & Untreated \\
\hline Tas F & 2005 & Europeans & $41-80 / \mathrm{NR}$ & $28 / 0$ & NR & $7(25)$ & Untreated \\
\hline Terzidis A & 2009 & Europeans & $64.1 \pm 10.4 / 64.3 \pm 10.7$ & $66 / 0$ & $3 / 6 / 16 / 41$ & NR & NR \\
\hline Werynska B & 2009 & Europeans & $50-75 / 28-77$ & $33 / 7$ & NR & $20(50)$ & Untreated \\
\hline Zhang ZH & 2003 & Chinese & NR & NR & NR & NR & NR \\
\hline
\end{tabular}

1: Not report

current meta-analysis [13-18, 20, 21, 23-26, 28-33, 35-37].

Among them, fourteen included articles regarding the association between the serum leptin levels and lung cancer [13-17, 20, 24, 25, 28, 29, 31-33, 37], and seven included articles about the association between the leptin expression levels in tissue and lung cancer [18, 21, 23, 26, $30,35,36]$. Ten of the 21 included articles were in English $[13-18,25,29,32,33]$ and eleven were in Chinese [20, $21,23,24,26,28,30,31,35-37]$. Among the studies, fourteen articles were conducted in Chinese people [15, $18,20,21,23,24,26,28-31,35-37]$, and seven studies were conducted in Europeans [13, 14, 16, 17, 25, 32, 33]. The characteristics of included studies are summarized in Tables 1, 2 and 3.

\section{Serum leptin}

\section{Overall meta-analysis}

All 14 eligible case-control studies (773 cases and 594 controls) were included in the meta-analysis to investigate the association between serum leptin concentrations and lung cancer. As showed in Table 4, the overall meta-analysis results of the random-effect model suggested that no relationship exists between levels of serum leptin and lung cancer $(\mathrm{SMD}=-0.09,95 \% \mathrm{CI}=-0.70$ 0.53, $P=0.780$ ) (Figure 2). However, a non-ignorable heterogeneity among studies was found ( $\left.I^{2}=96.2 \%\right)$. Therefore, we further conducted subgroup analyses of different specific effects that were expected to lead to heterogeneity.

\section{Subgroup meta-analysis}

At first, we carried out a subgroup analysis by language (English or Chinese), but we found no statistical significance between serum leptin concentrations and lung cancer regardless of whether the studies were published in English or in Chinese $(\mathrm{SMD}=-0.3395 \% \mathrm{CI}=-1.21-0.54, P=0.456$; $\mathrm{SMD}=0.33$, $95 \% \mathrm{CI}=-0.60-1.26, P=0.487$, respectively). We further analyzed the results by the lung cancer types, and the results showed that the serum leptin levels were not statistically different between the NSCLC group and the SCLC group (NSCLC: $\mathrm{SMD}=-0.53,95 \% \mathrm{CI}=-1.92-$ $0.86, P=0.454$; SCLC: $\mathrm{SMD}=-0.23,95 \% \mathrm{CI}=-0.64-0.18$, $P=0.270)$.

In the subgroup analysis of ethnicity, we found no association between serum leptin concentrations and lung cancer in Chinese people $(\mathrm{SMD}=0.50,95 \% \mathrm{CI}=-0.17-$ $1.17, P=0.144)$ and in Europeans $(\mathrm{SMD}=-0.70,95 \% \mathrm{CI}=-$ 1.79-0.39, $P=0.208$ ) (Figure 2). Interestingly, a weak statistical significance was found in the Chinese people of high-study quality group (NOS score $\geq 7,532$ cases and 443 controls) (Chinese: $\mathrm{SMD}=0.77,95 \% \mathrm{CI}=0.05-1.48$, 
Table 2: The levels of serum leptin in the each primary study

\begin{tabular}{|c|c|c|c|c|c|c|c|c|c|c|}
\hline \multirow{2}{*}{ Author } & \multirow{2}{*}{ Year } & \multicolumn{3}{|c|}{ Cases } & \multicolumn{3}{|c|}{ Controls } & \multirow{2}{*}{ Unit } & \multirow{2}{*}{ Method } & \multirow{2}{*}{$\begin{array}{c}\text { Study } \\
\text { Quality Score }\end{array}$} \\
\hline & & Mean & $\mathbf{S D}^{1}$ & $\mathbf{N}$ & Mean & SD & $\mathbf{N}$ & & & \\
\hline Aleman MR & 2002 & 7.11 & 0.91 & 76 & 18.50 & 4.17 & 30 & $\mathrm{ng} / \mathrm{ml}$ & RIA $^{2}$ & 7 \\
\hline $\begin{array}{l}\text { Carpagnano } \\
\text { GE }\end{array}$ & 2007 & 45.3 & 19.9 & 32 & 22.7 & 0.4 & 20 & $\mathrm{ng} / \mathrm{ml}$ & ELISA $^{3}$ & 7 \\
\hline Dong JH & 2009 & 8.67 & 2.28 & 64 & 5.75 & 1.70 & 70 & $\mathrm{ng} / \mathrm{ml}$ & ELISA & 7 \\
\hline Hong X & 2013 & 6.45 & 2.55 & 41 & 7.05 & 2.61 & 51 & $\mathrm{ng} / \mathrm{ml}$ & ELISA & 7 \\
\hline Jamieson NB & 2004 & 6.7 & 11.85 & 20 & 15.8 & 9.1 & 13 & $\mathrm{ng} / \mathrm{ml}$ & ELISA & 7 \\
\hline Kerenidi T & 2013 & 3.87 & 8.80 & 80 & 10.76 & 8.42 & 40 & $\mathrm{ng} / \mathrm{ml}$ & RIA & 7 \\
\hline Luo NP & 2008 & 5.72 & 1.16 & 42 & 4.18 & 0.51 & 30 & $\mathrm{ng} / \mathrm{ml}$ & RIA & 6 \\
\hline Mou WJ & 2014 & 3.78 & 3.30 & 27 & 1.73 & 0.94 & 27 & $\mathrm{ng} / \mathrm{ml}$ & RIA & 8 \\
\hline Song CH & 2014 & 9.66 & 5.73 & 126 & 4.75 & 2.98 & 60 & $\mathrm{ng} / \mathrm{ml}$ & ELISA & 7 \\
\hline Tao XN & 2003 & 1.50 & 0.80 & 34 & 3.20 & 1.80 & 25 & $\mathrm{ng} / \mathrm{ml}$ & RIA & 6 \\
\hline Tas F & 2005 & 6.2 & 44.5 & 28 & 12.5 & 6.88 & 15 & $\mathrm{ng} / \mathrm{ml}$ & ELISA & 5 \\
\hline Terzidis A & 2009 & 9.30 & 9.20 & 66 & 7.1 & 5.8 & 132 & $\mathrm{ng} / \mathrm{ml}$ & RIA & 7 \\
\hline Werynska B & 2009 & 9.0 & 8.85 & 40 & 10 & 7.6 & 15 & $\mathrm{ng} / \mathrm{ml}$ & ELISA & 6 \\
\hline \multirow[t]{2}{*}{ Zhang ZH } & 2003 & 6.81 & 6.3 & 97 & 6.44 & 4.59 & 66 & $\mathrm{ng} / \mathrm{ml}$ & RIA & 5 \\
\hline & & \multicolumn{3}{|c|}{ Cases with Weight Loss } & \multicolumn{3}{|c|}{ Cases without Weight Loss } & & & \\
\hline Hong X & 2013 & 5.12 & 1.38 & 15 & 7.22 & 2.76 & 26 & $\mathrm{ng} / \mathrm{ml}$ & ELISA & 7 \\
\hline Werynska B & 2009 & 6.0 & 7.8 & 20 & 12 & 9 & 20 & $\mathrm{ng} / \mathrm{ml}$ & ELISA & 6 \\
\hline
\end{tabular}

1: standard deviation; 2: radioimmunoassay; 3: enzyme-linked immunosorbent assay

Table 3: Characteristics of studies involving association between the tissue leptin expression and lung cancer a:

\begin{tabular}{|c|c|c|c|c|c|c|c|c|c|c|c|c|}
\hline \multirow{2}{*}{ Author } & \multirow{2}{*}{ Year } & \multirow{2}{*}{ Ethnicity } & \multirow{2}{*}{ Age } & \multirow{2}{*}{$\begin{array}{l}\text { Cancer/ } \\
\text { Normal }\end{array}$} & \multirow{2}{*}{ Type } & \multirow{2}{*}{$\frac{\text { Stage }}{\text { I/II/III/IV }}$} & \multicolumn{2}{|c|}{ Case } & \multicolumn{2}{|c|}{ Control } & \multirow{2}{*}{$\begin{array}{c}\mathbf{L N}^{3} \\
\text { metastases (+/-) }\end{array}$} & \multirow{2}{*}{ Status } \\
\hline & & & & & & & $\mathbf{P}^{1}$ & $\mathbf{N}^{2}$ & $\mathbf{P}$ & $\mathbf{N}$ & & \\
\hline Fang M & 2008 & Chinese & $45-77$ & $38 / 38$ & $\mathrm{NSCLC}^{4}$ & $6 / 15 / 17 / 0$ & 27 & 11 & 10 & 28 & $27 / 11$ & Untreated \\
\hline Guo SG & 2010 & Chinese & $31-72$ & $60 / 10$ & NSCLC & $12 / 30 / 18 / 0$ & 41 & 19 & 3 & 7 & $48 / 12$ & Untreated \\
\hline Liu Y & 2012 & Chinese & $59.8 \pm 8.6$ & $68 / 68$ & NSCLC & $18 / 25 / 25 / 0$ & 49 & 19 & 18 & 50 & $\mathrm{NR}^{5}$ & Untreated \\
\hline Sun LL & 2011 & Chinese & $47-73$ & $30 / 30$ & NSCLC & $12 / 8 / 10 / 0$ & 21 & 9 & 6 & 24 & $11 / 19$ & Untreated \\
\hline $\mathrm{Xu} \mathrm{YJ}$ & 2011 & Chinese & $28-75$ & $100 / 100$ & NSCLC & $15 / 41 / 44 / 0$ & 71 & 29 & 25 & 75 & $69 / 31$ & Untreated \\
\hline Yang Y & 2009 & Chinese & $57.8 \pm 5.7$ & $40 / 40$ & NSCLC & $15 / 17 / 8$ & 34 & 6 & 16 & 24 & $25 / 15$ & Untreated \\
\hline $\begin{array}{l}\text { Zhang } \\
\text { ZH }\end{array}$ & 2010 & Chinese & $45-77$ & $52 / 34$ & NSCLC & $9 / 22 / 21 / 0$ & 36 & 16 & 8 & 26 & $35 / 17$ & Untreated \\
\hline
\end{tabular}

b:

\begin{tabular}{|c|c|c|c|c|c|c|c|}
\hline \multirow[t]{2}{*}{ Author } & \multirow[t]{2}{*}{ Year } & \multirow[t]{2}{*}{ Method } & \multirow{2}{*}{$\begin{array}{c}\text { LN } \\
\text { metastases } \\
\text { Leptin (+/-) } \\
\end{array}$} & \multirow{2}{*}{$\begin{array}{c}\text { Non-LN } \\
\text { metastases } \\
\text { Leptin (+/-) } \\
\end{array}$} & \multirow[t]{2}{*}{$\mathbf{A b}^{7}$ types } & \multirow{2}{*}{$\begin{array}{c}\text { Semi- } \\
\text { quantitative } \\
\text { score }\end{array}$} & \multirow[t]{2}{*}{$\begin{array}{l}\text { Types of positive / } \\
\text { negative controls }\end{array}$} \\
\hline & & & & & & & \\
\hline Fang $\mathrm{M}$ & 2008 & $\mathrm{IHC}^{6}$ & $21 / 6$ & $6 / 5$ & Rabbit (donate) & $>25 \%$ & adipose tissue $/ \mathrm{PBS}^{8}$ \\
\hline Guo SG & 2010 & $\mathrm{IHC}$ & $37 / 11$ & $4 / 8$ & Rabbit (NR) & $>20 \%$ & adipose tissue / PBS \\
\hline Liu Y & 2012 & $\mathrm{IHC}$ & NR & NR & Goat ( Santa Cruz) & $>25 \%$ & adipose tissue / PBS \\
\hline Sun LL & 2011 & $\mathrm{IHC}$ & NR & NR & Rabbit (ZSGB-BIO) & $>10 \%$ & adipose tissue / PBS \\
\hline $\mathrm{Xu} \mathrm{YJ}$ & 2011 & $\mathrm{IHC}$ & $55 / 14$ & $16 / 15$ & Rabbit ( Santa Cruz) & $>25 \%$ & adipose tissue / PBS \\
\hline Yang Y & 2009 & $\mathrm{IHC}$ & $23 / 2$ & $11 / 4$ & Rabbit (ZSGB-BIO) & $>10 \%$ & adipose tissue / PBS \\
\hline Zhang ZH & 2010 & $\mathrm{IHC}$ & $27 / 8$ & $9 / 8$ & Rabbit (ZSGB-BIO) & $>25 \%$ & adipose tissue / PBS \\
\hline
\end{tabular}

1: positive; 2:negative; 3: lymph node; 4: non-small cell lung cancer; 5: not report; 6: immunological histological chemistry; 7: antibody; 8: phosphate-buffered saline 
Table 4: The pooled results of the serum leptin levels in lung cancer patients compared with in health controls

\begin{tabular}{|c|c|c|c|c|c|}
\hline & SMD $^{1}$ & $95 \% \mathrm{CI}^{2}$ & $\mathbf{P}$ & $I^{2}(\%)^{3}$ & Model \\
\hline Overall & -0.09 & $-0.70-0.53$ & 0.780 & 96.2 & Random \\
\hline \multicolumn{6}{|l|}{ Ethnicity } \\
\hline Chinese & 0.50 & $-0.17-1.17$ & 0.144 & 94.5 & Random \\
\hline Europeans & -0.70 & $-1.79-0.39$ & 0.208 & 96.8 & Random \\
\hline \multicolumn{6}{|c|}{ High quality group } \\
\hline Overall & -0.16 & $-1.03-0.71$ & 0.721 & 97.2 & Random \\
\hline Chinese & 0.77 & $0.05-1.48$ & 0.035 & 91.8 & Random \\
\hline Europeans & -0.93 & $-2.45-0.59$ & 0.229 & 97.8 & Random \\
\hline \multicolumn{6}{|c|}{ Publish language } \\
\hline In-English & -0.33 & $-1.21-0.54$ & 0.456 & 96.6 & Random \\
\hline In-Chinese & 0.33 & $-0.60-1.26$ & 0.487 & 95.9 & Random \\
\hline \multicolumn{6}{|l|}{ Cancer types } \\
\hline $\mathrm{SCLC}^{4}$ & -0.23 & $-0.64-0.18$ & 0.270 & 0 & Fixed \\
\hline $\mathrm{NSCLC}^{5}$ & -0.53 & $-1.92-0.86$ & 0.454 & 97.3 & Random \\
\hline Mixed & -0.30 & $-1.38-0.79$ & 0.594 & 95.8 & Random \\
\hline $\mathrm{NR}^{6}$ & 1.04 & $-0.02-2.09$ & 0.054 & 95.2 & Random \\
\hline \multicolumn{6}{|c|}{ Treatment status } \\
\hline Untreated & -0.65 & $-1.57-0.26$ & 0.159 & 95.9 & Random \\
\hline NR & 0.87 & $0.30-1.44$ & 0.003 & 92.3 & Random \\
\hline
\end{tabular}

1: standardized mean difference; 2: confidence interval; 3: I-squared; 4: small cell lung cancer; 5: non-small cell lung cancer; 6: not report

$P=0.035$; Europeans: $\mathrm{SMD}=-0.93,95 \% \mathrm{CI}=-2.45-0.59$, $P=0.229$ ) (Figure 3). Additionally, the subgroup analysis of treatment status indicated there is no statistical significance between serum leptin concentrations and lung cancer in the non-treatment group ( $\mathrm{SMD}=$ $0.65,95 \% \mathrm{CI}=-1.57-0.26, P=0.159)$, but there was a statistical association in the group that did not reported whether the patients received any treatment $(\mathrm{SMD}=0.87$, $95 \% \mathrm{CI}=0.30-1.44, P=0.003)$. All results of meta-analysis are summarized in Table 4.

\section{Sensitivity and meta-regression analysis}

To further investigate the possible source of heterogeneity, we executed a sensitivity analysis by sequentially excluding studies from the meta-analysis to investigate the influence of each study on the pooled results. The result of sensitivity analysis found that the pooled ORs were not materially altered, suggesting the stability of our meta-analysis (Figure 4). Moreover, we conducted a multivariate meta-regression analysis to assess the possible confounding factors. The results of multivariate meta-regression analysis showed that the publish year, ethnicity, cancer type, and study quality as confounding factors did not substantially affect heterogeneity (adjusted $P$ value is $0.079,0.816,0412$ and 0.366 , respectively). Further, no publication biases were found in the Begg's $(P=0.101)$ and the Egger's tests $(P=0.185)$ (Figure 5).

\section{Serum leptin in weight-losing group}

Only two case-control studies (81 cases and 67 controls) compared the difference of serum leptin concentration in the weight-losing group with that in the non-weight-losing group. The results of the meta-analysis indicated that the serum leptin levels were lower in the weight-losing group than in the non-weight-losing group $(\mathrm{SMD}=-0.80,95 \% \mathrm{CI}=-1.26-(-0.34), P=0.001)$ (Figure 6).

\section{Tissue leptin}

In total, seven studies reported the role of leptin expression in lung cancer tissue, and all of these articles were conducted in China. For the meta-analysis, the fixedeffect model was used because there is no heterogeneity. The results indicated evidence for a significant association between expression levels of leptin protein in tissue and lung cancer $(\mathrm{OR}=7.35,95 \% \mathrm{CI}=5.21-10.39, P<0.001)$ (Figure 7). Interestingly, further analysis found that tissue leptin protein levels were statistically different between the lymph node metastases group and the non-lymph node metastases group $(\mathrm{OR}=3.83,95 \% \mathrm{CI}=2.18-6.72, P<0.001)$ (Figure 8). No publication bias was found in either the 


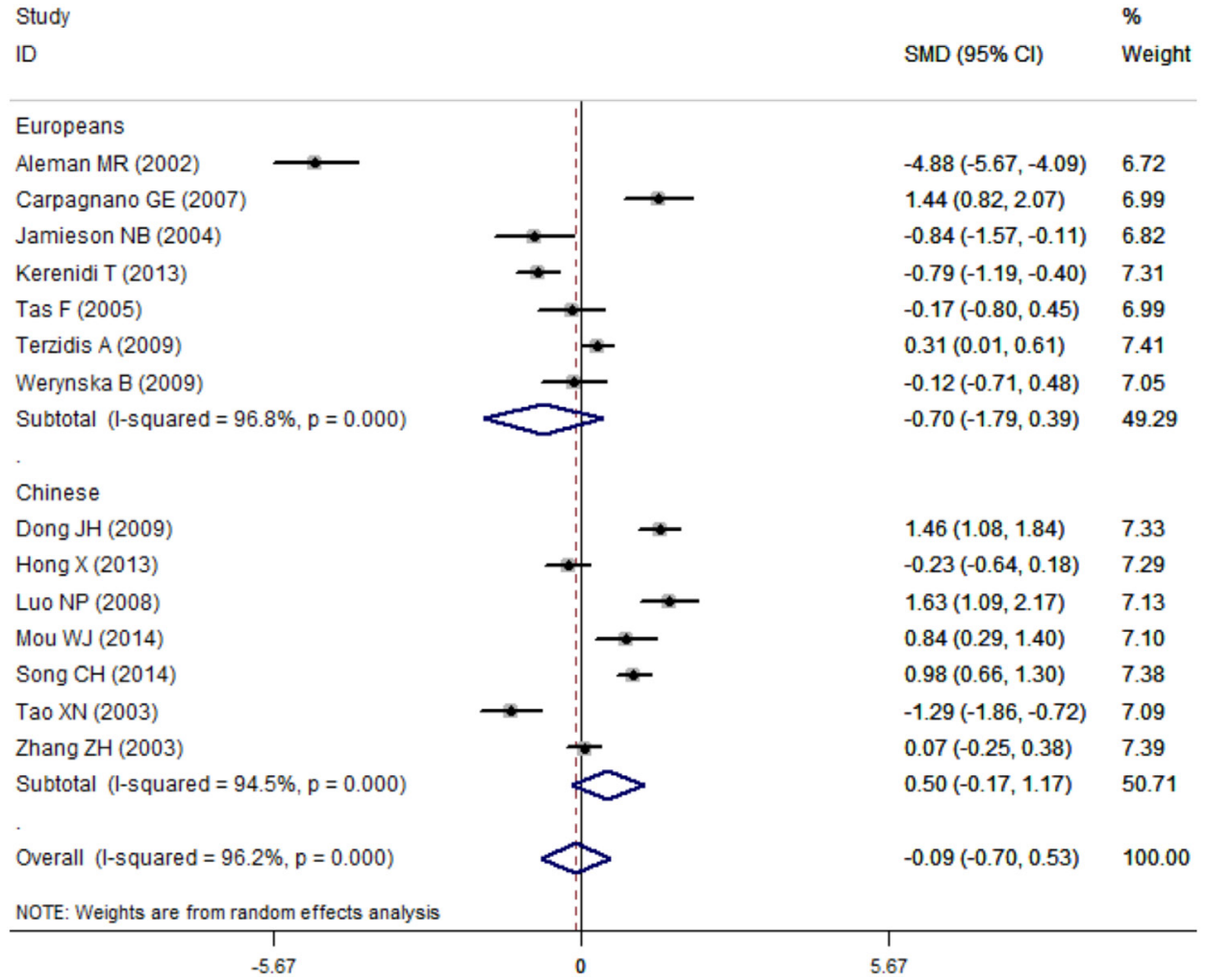

Figure 2: The results of association between the serum leptin levels and lung cancer. Failure of this confidence interval to include zero indicates no statistical difference between the case group and control group. Negative SMD value suggests the mean of serum leptin concentration of case group is lower than that of control group, while positive SMD value suggest the mean of case group was higher than control group.

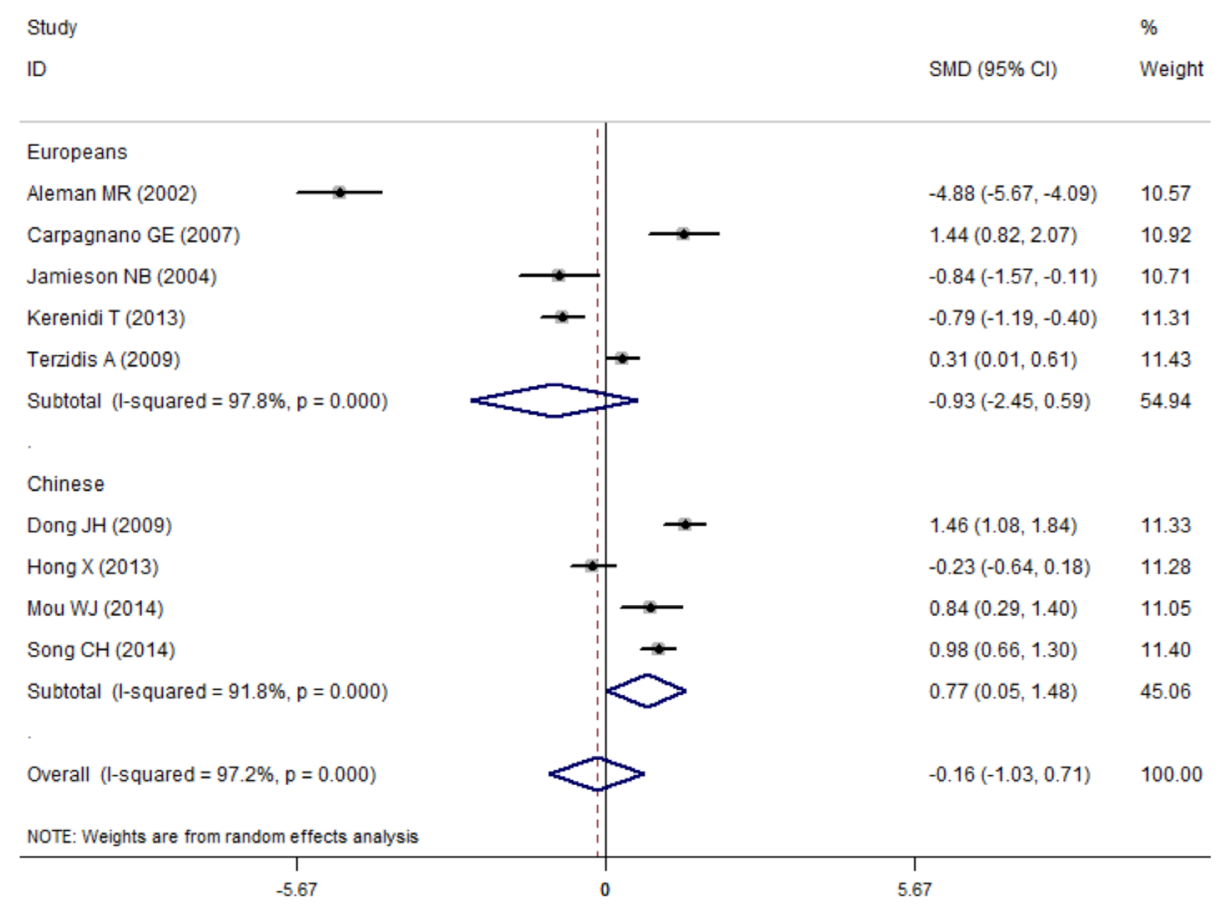

Figure 3: The subgroup analysis results of association between the serum leptin levels and lung cancer in high-study quality group (NOS score $\geq 7$ ). Failure of this confidence interval to include zero indicates no statistical difference between the case group and control group. Negative SMD value suggests the mean of serum leptin concentration of patients in high-study quality group is lower than that of control group, while positive SMD value suggest the mean of case group was higher than control group. 


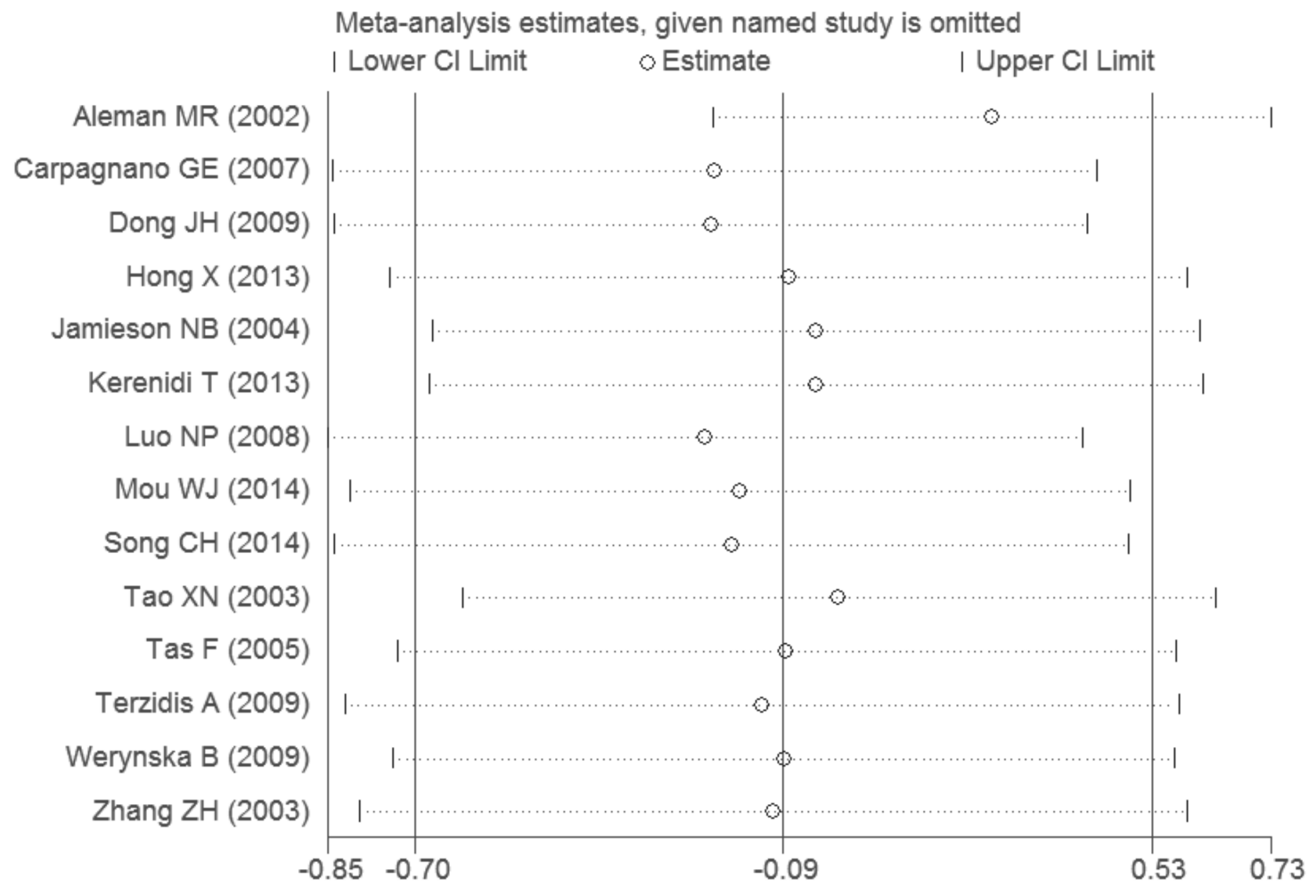

Figure 4: The result of sensitivity analysis on association between the serum leptin levels and lung cancer.

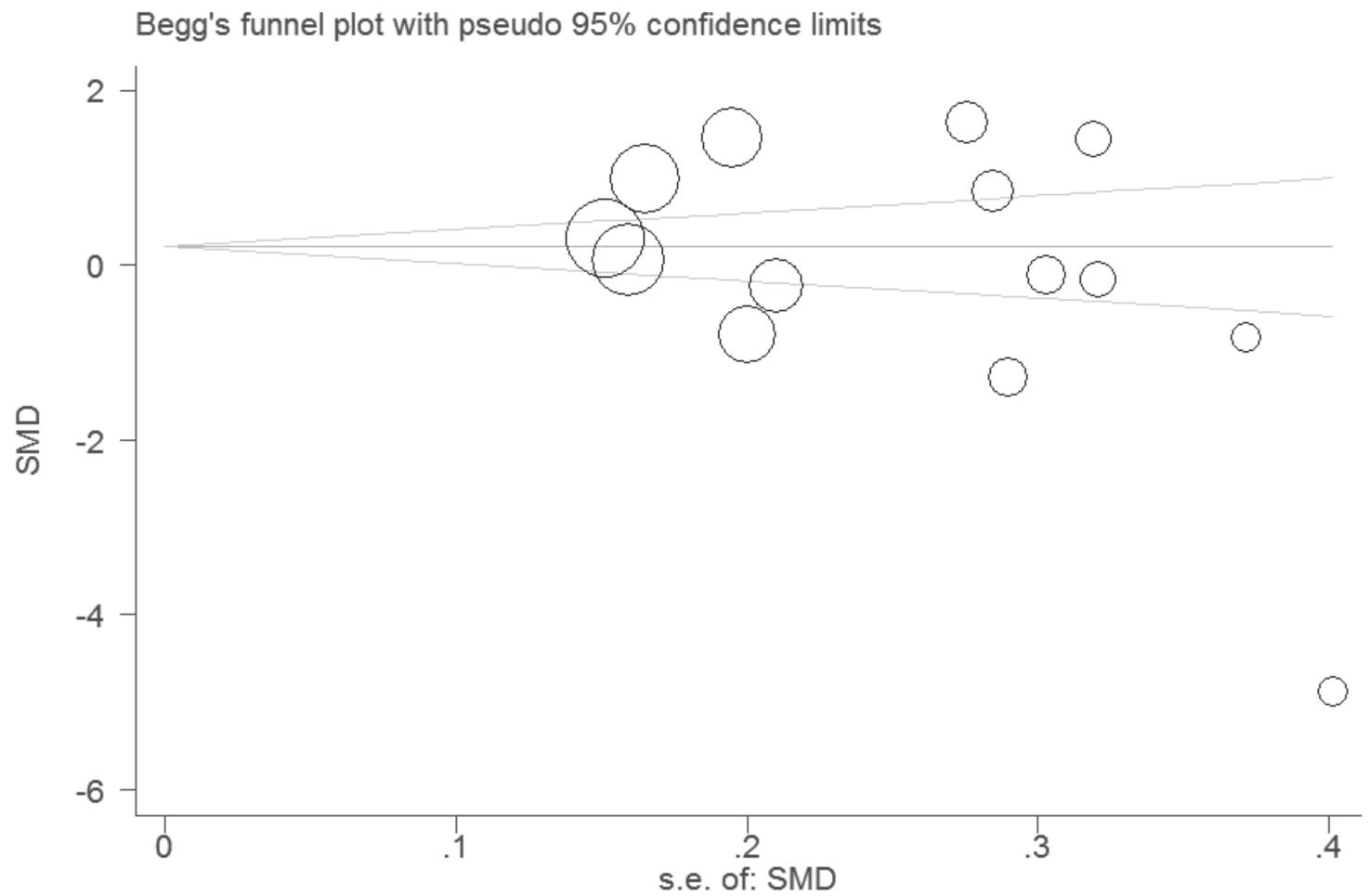

Figure 5: Funnel plot for evaluating publication bias on association between serum leptin levels and lung cancer. Each circle represents a separate study for the indicated association. These circles in the funnel plot implied no asymmetrical distribution, which means no publication biases were found. 


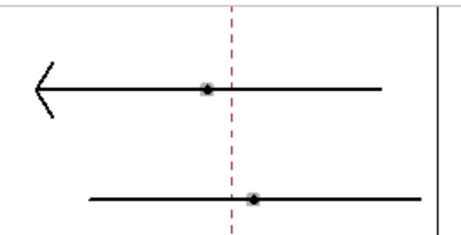

Figure 6: Comparison of differences of the serum leptin concentration in weight-losing group and in sustained weight group. Failure of this confidence interval to include zero indicates no statistical difference between the weight-losing group and sustained weight group. Negative SMD value suggests the mean of serum leptin concentration of weight-losing group is lower than that of sustained weight group, while positive SMD value suggest the mean of weight-losing group was higher than sustained weight group.

Study

ID

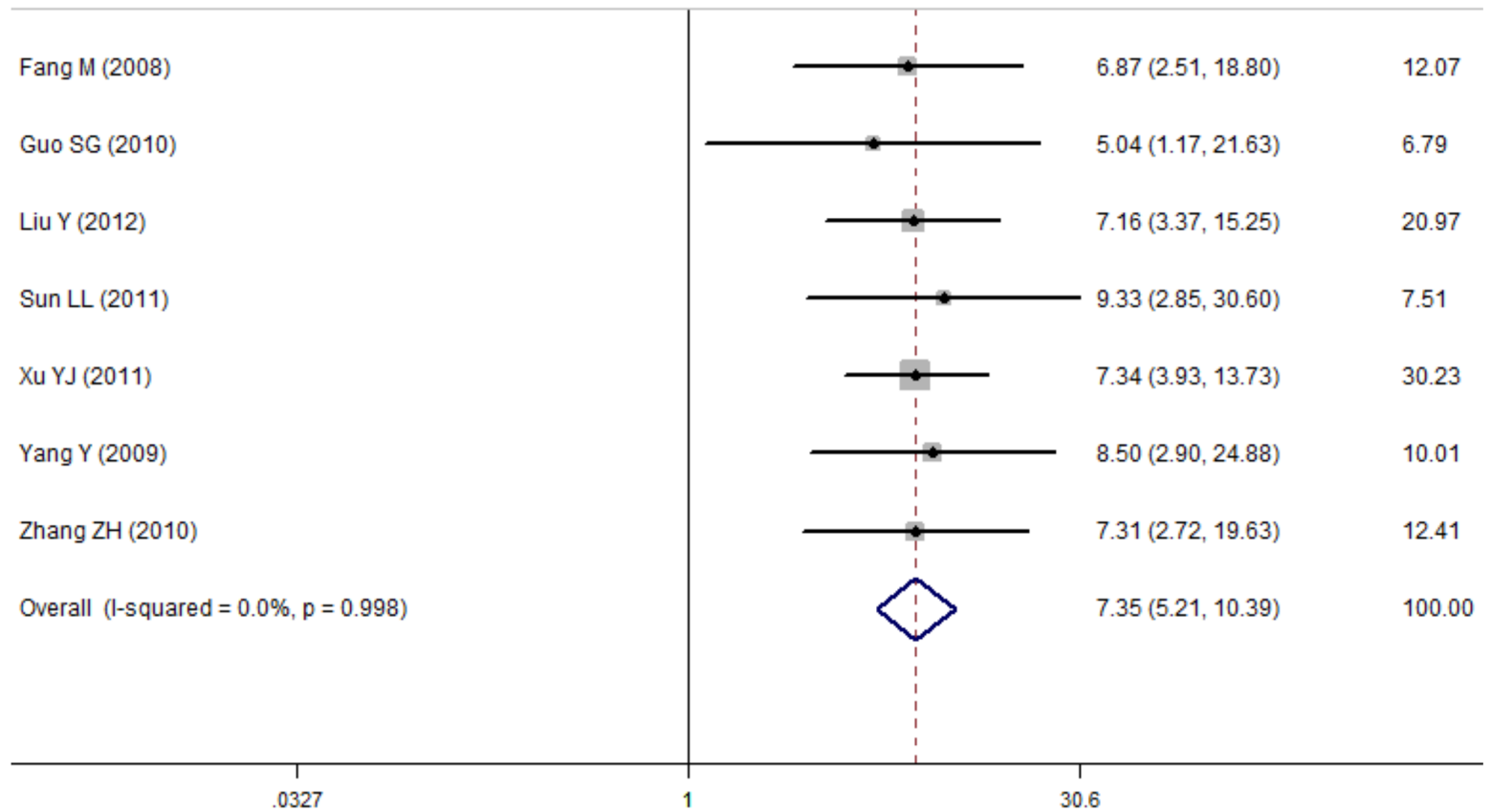

$\%$

Weight

Figure 7: Comparison of difference of the leptin expression in lung cancer tissue and in normal tissue. Failure of this confidence interval to include one indicates no statistical difference between the lung cancer tissue and normal tissue. Negative OR value suggests the mean of leptin expression of lung cancer tissue is lower than that of normal tissue, while positive OR value suggest the mean of lung cancer tissue was higher than normal tissue. 
Begg's $(P=1.0)$ or the Egger's test results $(P=0.804)$ (Figure 9).

\section{DISCUSSION}

Lung cancer is the most common cancer and the leading cause of cancer death in China [38, 39] (and worldwide [1]). It is well known that invasiveness and immortalization are important characteristics of cancer tissues, and postoperative recurrence and metastasis are the main reasons for ineffective treatment and death in patients with cancers. Therefore, the researchers are searching for specific biomarkers for early diagnosis of cancer or to distinguish the high risk of disease recurrence to achieve a better survival. Many studies have concluded that leptin may play a important role in the pathogenesis of lung cancer $[13,16,30]$, but these results are inconsistent. Therefore, we undertook a meta-analysis to determine the value of serum and tissue leptin in lung cancer.

In the current meta-analysis, there were 14 primary studies comparing the blood leptin concentrations in lung cancer patients and healthy controls. The overall results indicated that the serum leptin levels did not increase in the patients with lung cancer, as compared with the controls. However, we found a non-ignorable heterogeneity $\left(I^{2}=96.2 \%\right)$ between studies in the meta-analysis. Although the heterogeneity can be taken into account by using the random-effect model, it would increase the probability of type-I error. The following factors may have contributed to the significant heterogeneity: (1) the demographic characteristics and genetic backgrounds are different in European and Chinese populations; (2) the studied patients with lung cancer had different stages of cancer in each study; (3) different lung cancer types were included in the studies; (4) there were different ratios of patients with weight loss in each primary study; (5) different measuring methods were used in the primary studies; (6) the included studies were of differing quality; and (7) the included patients had different treatment statuses.

To identify the causes of heterogeneity, at first, we carried out a sensitivity analysis by sequentially excluding each study. Fortunately, the statistically similar results were obtained, suggesting the stability of the meta-analysis. Second, we also conducted a multivariate meta-regression analysis to further assess the possible confounding factors. However, the results suggested that the publish year, ethnicity, cancer type, and study quality, as the confounding factors, did not substantially affect the heterogeneity. Therefore, we finally conducted subgroup analyses of different specific effects.

The serum leptin levels still did not differ between the patients with lung cancer and the healthy participants

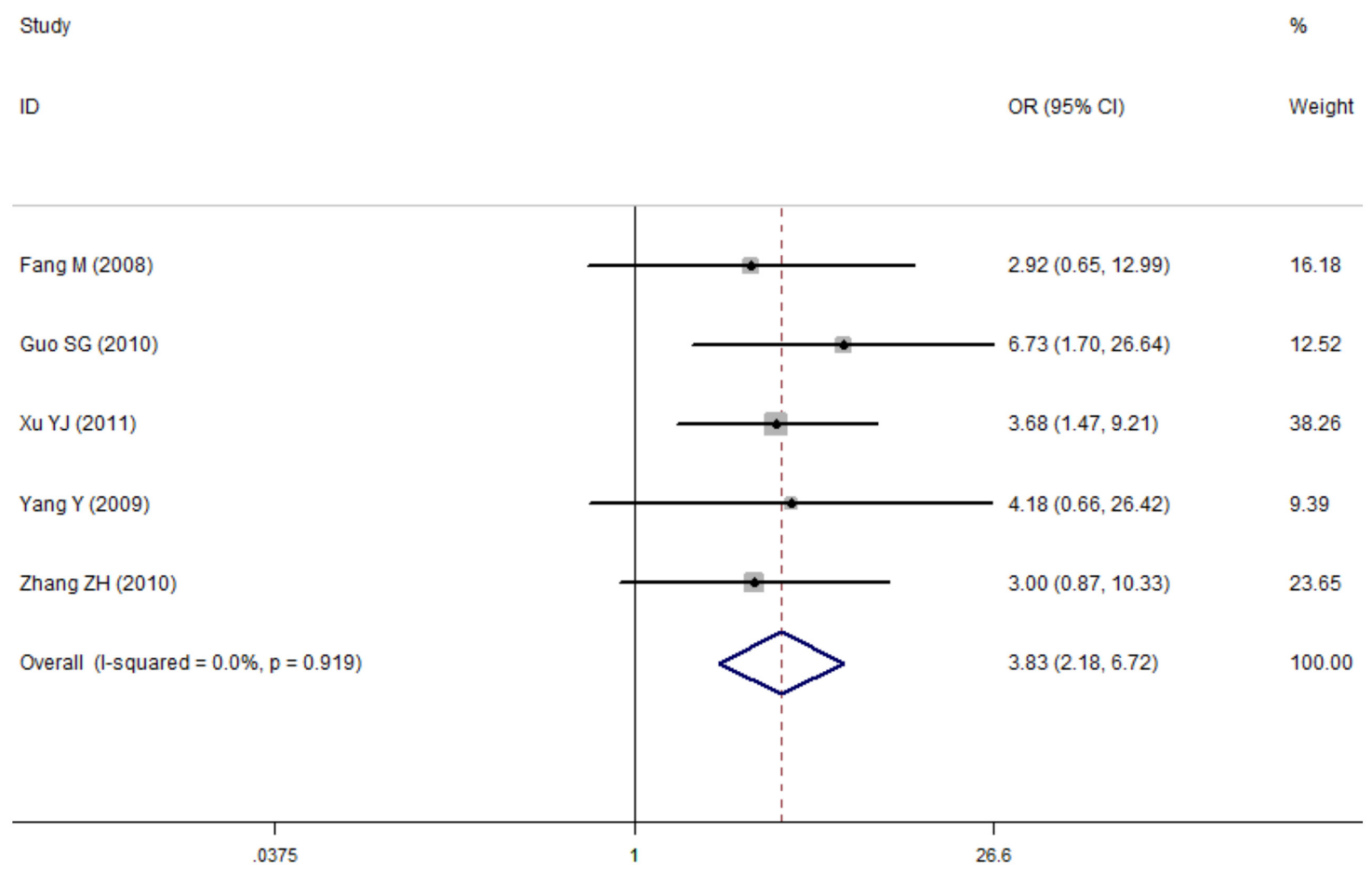

Figure 8: Comparison of difference of the leptin expression in the lymph node metastases group and the non-lymph node metastases group. Failure of this confidence interval to include one indicates no statistical difference between the lymph node metastases group and the non-lymph node metastases group. Negative OR value suggests the mean of leptin expression of lymph node metastases tissue is lower than that of non-lymph node metastases tissue, while positive OR value suggest the mean of lymph node metastases tissue was higher than non-lymph node metastases tissue. 
in the subgroups analyses (lung cancer types, published language, and treatment status). However, the subgroup analysis of ethnicity in the high-study quality group (NOS score $\geq 7$ ) indicated that the Chinese patients with lung cancer had higher serum leptin levels than the healthy population. Interestingly, our meta-analysis results were consistent with previous studies reporting that patients with hepatocellular carcinoma or prostate cancer have higher leptin levels than the normal population does [40, 41].

In addition, high expression levels of tumorassociated leptin receptor are thought to promote tumor growth and progression [42]. Therefore, we also carried out a meta-analysis to investigate the role of tissue leptin protein expression in lung cancer. The results indicated that the positive expression of leptin protein is obviously higher in lung cancer tissue than in normal tissue, especially significantly higher in the lymph node metastases group. Surprisingly, an earlier study also suggested that the increased detection of $o b-\mathrm{R}$ in ovarian cancers was associated with decreased survival [43]. In animal experiments, deficiency of the leptin receptor resulted in failure of mammary tumor formation [44]. The integrin-dependent migration of chondrosarcoma cells by involvement of IRS-1/PI3K-dependent activation of Akt was canceled with the knockdown of the long form of the leptin receptor [45]. Thus, even though the mechanism remains completely unclear, we speculate that leptin may play an important role in the pathogenesis of lung cancer and tumor metastasis, and the increased serum leptin level may possibly predict the diagnosis and progression of lung cancer. Further, the results of previous studies and the current study may help us to identify a new molecular marker for lung cancer diagnosis and a target for treatment.

Moreover, cancer anorexia-cachexia syndrome causes health deterioration and is a negative predictive factor of treatment response [33]. In addition, a previous study has shown that leptin is a protein hormone that functions as the afferent signal in a negative feedback loop regulating body mass [46]. Therefore, we analyzed the role of serum leptin in lung cancer patients with weight loss. Interestingly, the results suggested that serum leptin levels were lower in the weight-losing group than in the patients without weight loss and in the normal participants. Similar results were found in Weryńska's [33] and Jamieson's [25] studies. These results and our meta-analysis results indicate that changes of serum leptin levels should be considered to be the result of cachexia and not the cause of it, because its concentration depends on the total body fat mass. However, because only a small number of included studies refer to these results, the evidence is relatively weak.

There were several limitations of this meta-analysis. First, even if no publication bias was observed using several tests, published studies were identified in only a

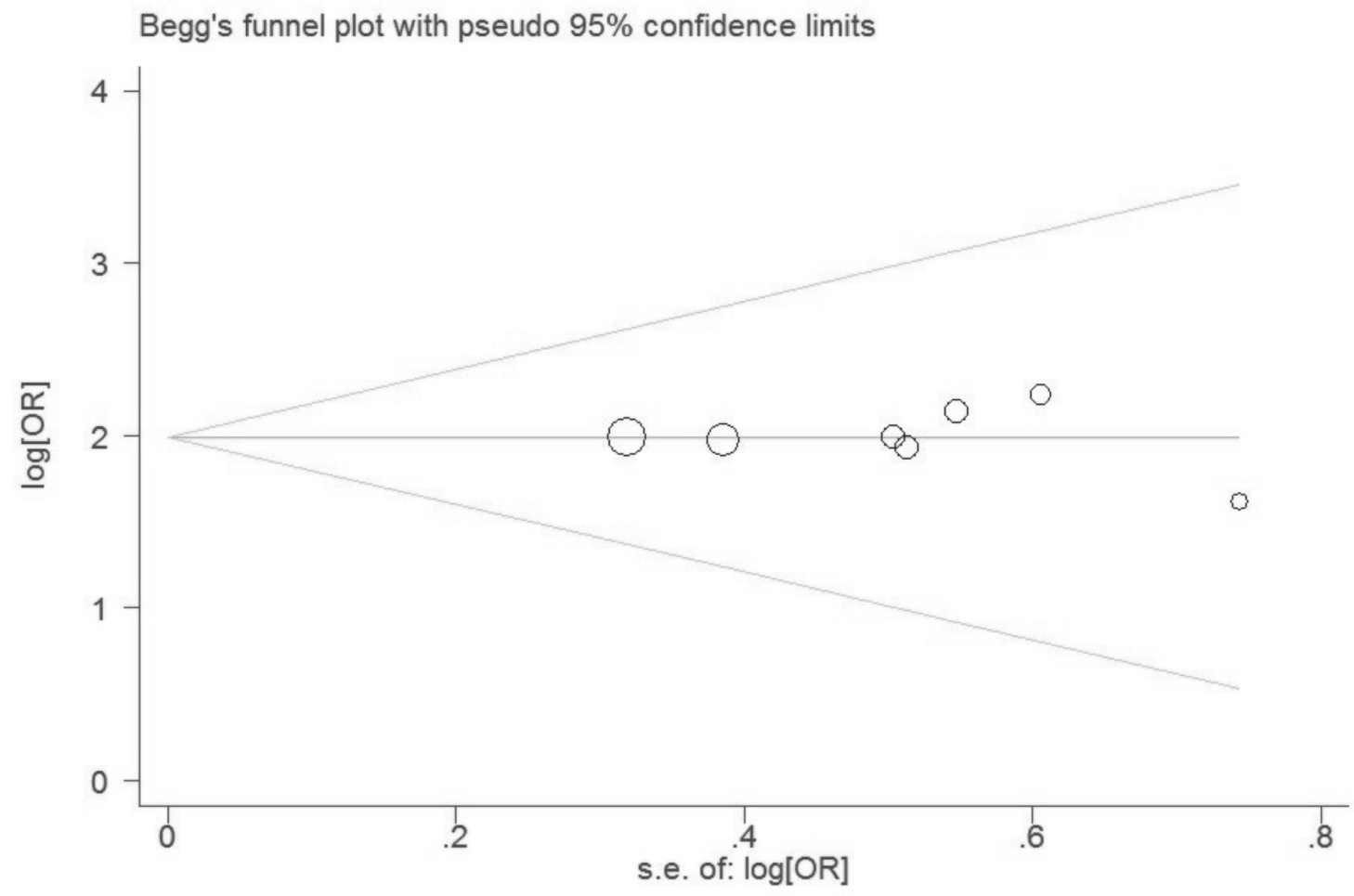

Figure 9: Funnel plot for evaluating publication bias on association between tissue leptin expression and lung cancer. Each circle represents a separate study for the indicated association. These circles in the funnel plot implied no asymmetrical distribution, which means no publication biases were found. 
few databases. Therefore, there may be other biases in the present study. Second, because sufficient data in primary studies are lacking, we failed to perform further subgroup analyses to investigate the other factors, such as gender, age, and cancer stage, which may have affected our results. Third, the subjects of this meta-analysis mainly came from China, so the results are possibly only applicable to the Chinese. Despite these limitations, we minimized the likelihood of bias through the whole process by creating a detailed protocol and by performing study identification, data selection, and statistical analysis, and we controlled for publication bias.

In summary, the current meta-analysis suggests that the serum and tissue leptin may play an important role in the pathogenesis of lung cancer and tumor metastasis, especially among Chinese. However, leptin may not be involved in cancer cachexia development. We recommend that researchers design more rigorous and uniform casecontrol or cohort studies to confirm the results in the future.

\section{MATERIALS AND METHODS}

\section{Literature search}

We performed a systematic literature search in the PubMed, Embase, Wanfang databases, and CNKI, to identify studies involving the role of leptin in lung cancer up to July 8, 2016. The key search terms were as follows: lung cancer, non-small-cell lung cancer, smallcell lung cancer, NSCLC, SCLC, and leptin. The metaanalysis was limited to studies published in English or Chinese. Additionally, we also conducted a web-based search using many commercial Internet search engines (such as Google and Baidu), using the same keywords. Further, the reference lists of the obtained articles were also reviewed.

\section{Study selection}

The inclusive criteria were as follows: (1) a study involving the role of serum leptin levels in lung cancer designed as a case-control study; (2) a study involving expression levels of leptin in tissue comparing lung cancer tissues with the normal tissues; (3) a primary study providing available data for calculating standardized mean difference (SMD) or odds ratio (OR) with $95 \%$ confidence interval (CI); and (4) the subjects of the study are human. The exclusion criteria were as follows: (1) lack of control cohort; (2) review and overlapping study; and (3) the study does not show the available data and is missing other essential information.

\section{Study quality score evaluation}

The qualities of included studies involving the role of serum leptin levels in lung cancer were assessed by using the Newcastle-Ottawa Scale (NOS) for case-control study, to investigate quality based on three aspects: selection, comparability, and exposure in the primary study. The total score ranged from 0 to $9(0-3,4-6$, and $7-9$ was considered low, moderate, and high quality, respectively).

\section{Data extraction}

Two independent authors (Xiang Tong and Yao Ma) collected the detail information and data from each study and used a predesigned data extraction Excel form. If there was any disagreement, the third author (Qilong Zhou) would further assess these articles. The information and data were extracted as follows: first author, publication year, country, ethnicity, sample size, age of participant, lung cancer type, stage of cancer, rate of weight loss, serum leptin levels (mean and standard deviation), leptin expression levels in tissue, treatment status, and test method.

\section{Statistical methods}

In the present study, the SMD with $95 \%$ CI was applied to compare the serum levels of leptin in the patients with lung cancer with the levels in healthy controls, whereas the OR and 95\% CI were used to investigate the leptin expression levels in lung cancer tissue and in normal tissue. We calculated the heterogeneity by the $\chi^{2}$ based Q-test and $I$-squared $\left(I^{2}\right)$ statistics test. The pooled effect size (SMD and OR) would be assessed using a randomeffect model if heterogeneity was considered statistically significant $\left(I^{2}>50 \%\right.$ and $\left.P<0.10\right)$; if not, the fixed-effect model was used. To determinate the ethnicity, lung cancer type, and study quality-specific effects, we also performed subgroup analyses of different specific effects.

In addition, publication bias was assessed using several methods [47, 48]. The Begg's and Egger's tests were used to assess publication bias. The visual inspection of asymmetry in funnel plots was carried out to further investigate the publication bias. All data analyses were conducted using the STATA 12.0 software.

\section{ACKNOWLEDGMENTS}

We thank Elsevier Language Editing Services for its linguistic assistance during the preparation of this manuscript.

\section{CONFLICTS OF INTEREST}

The authors declare that they have no conflicts of interest.

\section{REFERENCES}

1. Siegel RL, Miller KD, Jemal A. Cancer statistics, 2015. CA Cancer J Clin. 2015; 65: 5-29. 
2. Zhang ZH, Han YW, Liang H, Wang LM. Prognostic value of serum CYFRA21-1 and CEA for non-small-cell lung cancer. Cancer Med. 2015; 4: 1633-1638.

3. Wang XB, Li J, Han Y. Prognostic significance of preoperative serum carcinoembryonic antigen in non-small cell lung cancer: a meta-analysis. Tumour Biol. 2014; 35: 10105-10110.

4. Zhang R, Shao F, Wu X, Ying K. Value of quantitative analysis of circulating cell free DNA as a screening tool for lung cancer: a meta-analysis. Lung Cancer. 2010; 69: 225-231.

5. Liao C, Yu Z, Guo W, Liu Q, Wu Y, Li Y, Bai L. Prognostic value of circulating inflammatory factors in non-small cell lung cancer: a systematic review and meta-analysis. Cancer Biomark. 2014; 14: 469-481.

6. Schmidt LH, Kuemmel A, Schliemann C, Schulze A, Humberg J, Mohr M, Gorlich D, Hartmann W, Brockling S, Marra A, Hillejan L, Goletz S, Karsten U, et al. Blood group antigen A type 3 expression is a favorable prognostic factor in advanced NSCLC. Lung Cancer. 2016; 92: 8-14.

7. Malli F, Papaioannou AI, Gourgoulianis KI, Daniil Z. The role of leptin in the respiratory system: an overview. Respir Res. 2010; 11: 152 .

8. Lago F, Dieguez C, Gomez-Reino J, Gualillo O. Adipokines as emerging mediators of immune response and inflammation. Nat Clin Pract Rheumatol. 2007; 3: 716-724.

9. Otero M, Lago R, Lago F, Casanueva FF, Dieguez C, Gomez-Reino JJ, Gualillo O. Leptin, from fat to inflammation: old questions and new insights. FEBS Lett. 2005; 579: 295-301.

10. Liu CL, Chang YC, Cheng SP, Chern SR, Yang TL, Lee JJ, Guo IC, Chen CP. The roles of serum leptin concentration and polymorphism in leptin receptor gene at codon 109 in breast cancer. Oncology. 2007; 72: 75-81.

11. Chia VM, Newcomb PA, Lampe JW, White E, Mandelson MT, McTiernan A, Potter JD. Leptin concentrations, leptin receptor polymorphisms, and colorectal adenoma risk. Cancer Epidemiol Biomarkers Prev. 2007; 16: 2697-2703.

12. Stolzenberg-Solomon RZ, Newton CC, Silverman DT, Pollak M, Nogueira LM, Weinstein SJ, Albanes D, Mannisto S, Jacobs EJ. Circulating Leptin and Risk of Pancreatic Cancer: A Pooled Analysis From 3 Cohorts. Am J Epidemiol. 2015; 182: 187-197.

13. Terzidis A, Sergentanis TN, Antonopoulos G, Syrigos C, Efremidis A, Polyzos A, Dessypris N, Petridou ET. Elevated serum leptin levels: a risk factor for non-small-cell lung cancer? Oncology. 2009; 76: 19-25.

14. Carpagnano GE, Spanevello A, Curci C, Salerno F, Palladino GP, Resta O, Di Gioia G, Carpagnano F, Foschino Barbaro MP. IL-2, TNF-alpha, and leptin: local versus systemic concentrations in NSCLC patients. Oncol Res. 2007; 16: 375-381.

15. Song CH, Liao J, Deng ZH, Zhang JY, Xue H, Li YM, Liang C, Han M, Zhang K, Yan GT. Is leptin a predictive factor in patients with lung cancer? Clin Biochem. 2014; 47: 230-232.

16. Aleman MR, Santolaria F, Batista N, de La Vega M, Gonzalez-Reimers E, Milena A, Llanos M, Gomez-Sirvent JL. Leptin role in advanced lung cancer. A mediator of the acute phase response or a marker of the status of nutrition? Cytokine. 2002; 19: 21-26.

17. Kerenidi T, Lada M, Tsaroucha A, Georgoulias P, Mystridou $\mathrm{P}$, Gourgoulianis KI. Clinical significance of serum adipokines levels in lung cancer. Med Oncol. 2013; 30: 507.

18. Xu YJ, Shao YF, Zhao X, Geng YT, Wang K, Yin YM. Expression and clinical significance of leptin, the functional receptor of leptin (OB-Rb) and HER-2 in non-small-cell lung cancer: a retrospective analysis. J Cancer Res Clin Oncol. 2011; 137: 1841-1848.

19. Li HQ, Zhu SY, Jia XM, Zhao J, Wang HQ. The expression of leptin receptor OB-R and its angiogenic effect in lung cancer (Chinese). Journal of Clinical Pulmonary Medicine. 2009; 14: 1441-1442.

20. Dong JH, Zhao YP, Ma JY. Relationship of serum leptin, VEGF and lung cancer (Chinese). China Medicine. 2009; 4: 258-259.

21. Fang M, Zhang YB, Zhang ZH, Fan XY, Zhao H, Wang DB, Lu YJ, Wang WM, Liu RY. Clinicopathologic research on the expression of leptin and its fuctional receptor $\mathrm{OB}-\mathrm{Rb}$ in non-small cell lung cancer (Chinese). Tumor. 2008; 28: 342-345.

22. Gulen ST, Karadag F, Karul AB, Kilicarslan N, Ceylan E, Kuman NK, Cildag O. Adipokines and systemic inflammation in weight-losing lung cancer patients. Lung. 2012; 190: 327-332.

23. Guo SG, Chu DJ, Bao WH, Liu Y, Hu ZX, Sun SM. The relationship between the expression of leptin in human nonsmall cell lung cancer and angiogenesis of tumor (Chinese). Chinese Journal of Clinical Medicine. 2010; 17: 179-181.

24. Hong X, Tian FM, Chen GY, Cui BH, Wang M, Yang CY. Expression of serum leptin in small cell lung cancer and its clinical significance (Chinese). Journal of Oncology. 2013: 427-430.

25. Jamieson NB, Brown DJ, Michael Wallace A, McMillan DC. Adiponectin and the systemic inflammatory response in weight-losing patients with non-small cell lung cancer. Cytokine. 2004; 27: 90-92.

26. Liu Y, Wu FL, Hu N, Yang CX. Expressions of leptin and leptin receptor in lung cancer (Chinese). Journal of Basic and Clinical Oncology. 2013; 25: 483-485.

27. Lu XF, Yang XQ, Yang YX, Gu XQ, Liao L, Wang D. Evaluation of serum cytokines in small cell lung cancer and its clinical significance (Chinese). Chinese Journal of Lung Cancer. 2012; 15: 11-16.

28. Luo NP, Liu HG, Sun XM, Chen YJ. Relationship between leptin and neuropeptide $\mathrm{Y}$ levels in patients with different kinds of tumors (Chinese). Journal of Radioimmanology. 2008; 21: 197-199. 
29. Mou W, Xue H, Tong H, Sun S, Zhang Z, Zhang C, Sun Q, Dong J, Wen X, Yan G, Tian Y. Prognostic value of serum leptin in advanced lung adenocarcinoma patients with cisplatin/pemetrexed chemotherapy. Oncol Lett. 2014; 7 : 2073-2078.

30. Sun LL, Che SY, Yu HS, Jiang HD. Expression and clinicaI significance of Leptin, OB-Rb, VEGF in tissue of NSCLC (Chinese). Shandong Medical Journal. 2011; 51: 20-22.

31. Tao XN, Zhang XJ, Jin Y, Bai M. Detection of serum leptin, TNF- $\alpha$ and their correlated analysis in patients with lung cancer (Chinese). Journal of Clinical Internal Medicine. 2003; 20: 416-418.

32. Tas F, Duranyildiz D, Argon A, Oguz H, Camlica H, Yasasever V, Topuz E. Serum levels of leptin and proinflammatory cytokines in advanced-stage non-small cell lung cancer. Med Oncol. 2005; 22: 353-358.

33. Weryńska B, Kosacka M, Gołecki M, Jankowska R. Leptin serum levels in cachectic and non-cachectic lung cancer patients. Pneumonol Alergol Pol. 2009; 77: 500-506.

34. $\mathrm{Xu} \mathrm{CH}$, Yu KL, Zhang Y. The significance of serum ghrelin and leptin levels in lung caner patients (Chinese). Chinese Journal of Respiratory and Critical Care Medicine. 2010; 9: 537-538.

35. Yang Y, Feng Y, Xia L. Expressions of leptin and vascular endothelial growth factor in non-small cell lung cancer (Chinese). Jiangsu Medical Journal. 2009: 872-874.

36. Zhang ZH, Hu BD, Yu M, Zhang YB. Expressionsofleptin, STAT3, p-STAT3 and bcl-2 in lung cancer and their clinical significance (Chinese). Tumor. 2010; 30: 529-534.

37. Zhang ZH, Zhu BD, Ma LW. An analysis of the relationship between serum leptin and nutritional status in patients with lung cancer (Chinese). China Cancer. 2003; 12: 409-411.

38. Zheng R, Zeng H, Zuo T, Zhang S, Qiao Y, Zhou Q, Chen W. Lung cancer incidence and mortality in China, 2011. Thorac Cancer. 2016; 7: 94-99.
39. Chen W, Zheng R, Baade PD, Zhang S, Zeng H, Bray F, Jemal A, Yu XQ, He J. Cancer statistics in China, 2015. CA Cancer J Clin. 2016.

40. Sadik NA, Ahmed A, Ahmed S. The significance of serum levels of adiponectin, leptin, and hyaluronic acid in hepatocellular carcinoma of cirrhotic and noncirrhotic patients. Hum Exp Toxicol. 2012; 31: 311-321.

41. Arisan ED, Arisan S, Atis G, Palavan-Unsal N, Ergenekon E. Serum adipocytokine levels in prostate cancer patients. Urol Int. 2009; 82: 203-208.

42. Vansaun MN. Molecular pathways: adiponectin and leptin signaling in cancer. Clin Cancer Res. 2013; 19: 1926-1932.

43. Uddin S, Bu R, Ahmed M, Abubaker J, Al-Dayel F, Bavi P, Al-Kuraya KS. Overexpression of leptin receptor predicts an unfavorable outcome in Middle Eastern ovarian cancer. Mol Cancer. 2009; 8: 74.

44. Cleary MP, Juneja SC, Phillips FC, Hu X, Grande JP, Maihle NJ. Leptin receptor-deficient MMTV-TGF-alpha/ Lepr(db)Lepr(db) female mice do not develop oncogeneinduced mammary tumors. Exp Biol Med (Maywood). 2004; 229: 182-193.

45. Yang SN, Chen HT, Tsou HK, Huang CY, Yang WH, Su CM, Fong YC, Tseng WP, Tang CH. Leptin enhances cell migration in human chondrosarcoma cells through OBR1 leptin receptor. Carcinogenesis. 2009; 30: 566-574.

46. Zhang Y, Proenca R, Maffei M, Barone M, Leopold L, Friedman JM. Positional cloning of the mouse obese gene and its human homologue. Nature. 1994; 372: 425-432.

47. Chaimani A, Mavridis D, Salanti G. A hands-on practical tutorial on performing meta-analysis with Stata. Evid Based Ment Health. 2014; 17: 111-116.

48. Egger M, Davey Smith G, Schneider M, Minder C. Bias in meta-analysis detected by a simple, graphical test. Bmj. 1997; 315: 629-634. 